\title{
The many faces of Th17 cells
}

\author{
Anneli Peters ${ }^{\mathrm{a}}$, Youjin Lee ${ }^{\mathrm{a}}$, and Vijay K. Kuchroo ${ }^{\mathrm{a}}$ \\ aCenter for Neurologic Diseases, Brigham and Women's Hospital, Harvard Medical School, \\ Boston, Massachusetts 02115, USA
}

\begin{abstract}
Th17 cells have been shown to be strong inducers of tissue inflammation and autoimmune diseases. However, not all Th17 cells are pathogenic and increasing data suggests that Th17 cells may come in different flavors. Thus, Th17 cells cannot be described using a narrow schematic, but instead Th17 cells comprise a wide spectrum with a range of effector phenotypes. Here, we review the key factors that generate such diversity, as well as the cytokines and transcription factors that are differentially expressed in pathogenic and nonpathogenic Th17 cells. This new knowledge can be used to identify molecules that make Th17 cells pathogenic and determine how these cells could be targeted to suppress autoimmune diseases.
\end{abstract}

\section{Introduction}

Through the identification of their differentiation factors IL- 6 and TGF- $\beta 1$, as well as their unique transcription factor ROR- $\gamma \mathrm{t}$ [1], Th17 cells have been classified as an independent $\mathrm{T}$ helper cell subset. Bettelli et al. and Veldhoen et al. simultaneously described IL-6 and TGF$\beta 1$ as crucial factors for the generation of IL-17 producing Th17 cells from naïve $\mathrm{CD} 4^{+}$cells $[2,3]$. The requirement of TGF- $\beta$ for the generation of Th17 cells in vitro and in vivo has been demonstrated by using CD4dnTGF- $\beta$ RII mice, TGF- $\beta$-T cell transgenic mice, and T cell specific TGF- $\beta 1$-deficient mice, respectively $[2,4,5]$. Furthermore, it has been shown that $\mathrm{T}$ cells can endogenously produce TGF- $\beta$ to promote Th17 differentiation in an autocrine manner [5,6]. However, a recent study by Ghoreschi et al. challenges the concept of TGF- $\beta$ as a crucial component for the development of pathogenic Th17 cells, and proposes that Th17 cells can be generated independently of TGF- $\beta$ [7].

These "alternative" Th17 cells, differentiated in the presence of IL-6, IL-1 $\beta$ and IL-23, possess a different expression profile in terms of cytokines, transcription factors and surface molecules. When "classical" Th17 cells, induced by TGF- $\beta 1$ plus IL-6, were compared to the alternatively induced Th17 cells, the "alternative" Th17 cells were more pathogenic. Importantly, one has to note that the authors compared Th17 cells generated via IL-6, IL-1 $\beta$, and IL-23 with Th17 cells generated with TGF- $\beta 1$ and IL-6, but in the absence of IL-23. Thus introducing more than one variable (not only TGF- $\beta$, but also IL-23), it is not possible to clearly attribute the observed changes in the expression profile to the lack of TGF- $\beta$ signaling, since the observed changes may also be due to IL-23 signaling in "alternative" Th17 cells. Considering that IL-23 has been described to be essential for the pathogenicity

(C) 2011 Elsevier Ltd. All rights reserved.

Corresponding author: Vijay K. Kuchroo, vkuchroo@ rics.bwh.harvard.edu, phone number: 617525 5350, fax number: 6175255566.

Publisher's Disclaimer: This is a PDF file of an unedited manuscript that has been accepted for publication. As a service to our customers we are providing this early version of the manuscript. The manuscript will undergo copyediting, typesetting, and review of the resulting proof before it is published in its final citable form. Please note that during the production process errors may be discovered which could affect the content, and all legal disclaimers that apply to the journal pertain. 
and terminal differentiation of Th17 cells by multiple groups [8-13], in our opinion the best way to determine the effect of TGF- $\beta$ on Th17 differentiation, expression profile and pathogenicity would be the comparison of Th17 cells generated via TGF- $\beta+$ IL-1 $\beta$ + IL-6+IL-23 with Th17 cells generated via IL- $1 \beta+$ IL-6+IL-23. Whether TGF- $\beta$ is required or dispensable has also been extensively discussed for human Th17 cells; early studies presented evidence that human Th17 cells develop in the absence of TGF- $\beta[14,15]$, while more recent studies suggested that the presence of TGF- $\beta$ is essential for naïve human T helper cells to become Th17 cells [16,17]. Th17 cells generated by these two different differentiation protocols may represent "classical" and "alternative" human Th17 cells, analogous to what has been described in mice. It is difficult to prove that Th17 cells can be generated in an in vivo setting in the complete absence of TGF- $\beta$ considering that TGF- $\beta$ as well as its receptor is ubiquitously expressed and that activated T cells and especially Th17 cells themselves are a major source of TGF- $\beta$ [6]. In addition, there are three different forms of TGF- $\beta$ that signal through the same receptor, and it would be necessary to effectively block all three forms of TGF- $\beta$ before arriving at the conclusion that Th17 cells can be generated in complete absence of TGF- $\beta$ signaling. Nonetheless, the study by Ghoreschi et al. [7] indicates that Th17 cells may come in different flavors and vary in terms of their expression profile, effector functions and pathogenicity, and also confirms an earlier study by McGeachy et al. [10], which described that the generation of pathogenic Th17 cells is dependent on IL-23 exposure, whereas Th17 cells generated via TGF- $\beta 1$ and IL- 6 are nonpathogenic due to their production of IL-10.

\section{"Classical" and "alternative" Th17 cells}

Whether a naïve T cell becomes a more "classical" or an "alternative" Th17 cell or anything in between depends on the composition of the cytokine milieu over time during the differentiation process. The amount/availability of both IL-23 and TGF- $\beta$ have emerged as major skewing factors, i.e. abundance of TGF- $\beta$ together with relative lack of IL-23 favors generation of "classical" Th17 cells, while the presence of IL-23 promotes the generation of "alternative" Th17 cells (Figure 1). In addition, many other cytokines, such as IL-1 $\beta$, IL-21, IL-10 and IFN- $\gamma$, will influence the fate of the emerging Th17 cell and fine-tune their final effector phenotype. At the molecular level, this effector phenotype is a result of the network of active transcription factors. Transcription factors that are differentially expressed in "classical" vs. "alternative" Th17 cells will cause differential cytokine expression and effector functions. Selected differentially expressed genes that characterize the opposite ends of the Th17 cell spectrum are outlined below.

\section{Production of IFN-y by Th17 cells}

The most prominent example of differentially expressed transcription factors is probably $\mathrm{T}$ bet, which is the master transcription factor in Th1 cells and controls the expression of IFN$\gamma$. T-bet and IFN- $\gamma$ are Th1-specific and it has been demonstrated that Th17 cells can be generated completely independently of both T-bet and IFN- $\gamma[18,19]$. However, - although in vitro generated Th17 cells produce no or little IFN- $\gamma$-, Th17 cells generated in vivo often co-produce IFN- $\gamma$. This is especially true for Th17 cells that are present in the target organs of various autoimmune disease models, including the CNS during EAE [1,20] and the colon during colitis $[21,22]$. Until recently, it was not clear whether those $\mathrm{IL}-17^{+} \mathrm{IFN}-\gamma^{+}$double producers arise from Th1 or Th17 cells. This conundrum has now been solved by the Stockinger group [23], who demonstrated in a series of elegant fate mapping experiments that all double producers are derived from Th17 cells. Importantly, they and others [7,2426] have suggested that expression of T-bet and IFN- $\gamma$ in Th17 cells is dependent on IL-23, but inhibited by TGF- $\beta$ and thus is a characteristic of "alternative" rather than "classical" Th17 cells (Figure 1). Interestingly, it has been shown recently that T-bet inhibits expression 
of ROR- $\gamma$ t by sequestering the transactivation factor Runx1 [27], which might explain why IL- $17^{+}$IFN- $\gamma^{+}$double producers have lower expression of ROR- $\gamma \mathrm{t}$ compared to IL- $17^{+}$single positive T cells [23]. Since IL-17 ${ }^{+} \mathrm{IFN}-\gamma^{+}$double producers are enriched in the target organs of several autoimmune disease models and since T-bet deficient animals are protected in those same disease models [28,29], it has been suggested that double producers are particularly pathogenic in tissue inflammation and autoimmunity. However, it has not been shown conclusively, whether the production of IFN- $\gamma$ by Th17 cells is a protective or pathogenic mechanism. Our initial studies show that IFN- $\gamma$ is not required for the pathogenicity of Th17 cells, but that IFN- $\gamma$-deficient Th17 cells are just as pathogenic as their IFN- $\gamma$ producing counterparts (Liu and Kuchroo, unpublished observation). Without a doubt Th17 cells are more plastic than for example Th1 cells: "Classical" Th17 cells are less stable per se and switch over/dedifferentiate into IFN- $\gamma$ producers relatively easily in vivo [13,24,30,31]. "Alternative" Th17 cells - due to their exposure to IL-23 - are more "terminally differentiated" and therefore maintain a stable IL-17 production [12,13,32,33], but often co-produce IFN- $\gamma$ in the target organ. Considering the amount of tissue damage that can be induced by Th17 cells and the fact that IFN- $\gamma$-deficient animals develop exacerbated disease in several autoimmune disease animal models [34-36], it is possible that IFN- $\gamma$ produced by Th17 cells ultimately serves to limit Th17-induced inflammation. Since IFN- $\gamma$ inhibits Th17 differentiation [18,19], by producing IFN- $\gamma$ "alternative" Th17 cells may also inhibit de novo generation of Th17 cells and promote de novo Th1 differentiation in the target organ. However, it remains to be determined whether the switch to IFN- $\gamma$ is actually beneficial or detrimental for the development of tissue inflammation and autoimmunity.

\section{Regulation of Th17 cells by IL-10}

Th17 cells have been described to produce variable amounts of IL-10 and several studies implicate that exposure of Th17 cells to IL- 23 diminishes IL-10 production, whereas TGF- $\beta$ promotes the production of IL-10 $[10,26]$. This pattern is paralleled by the transcription factor c-Maf, which is probably an important driver for IL-10 production in Th17 cells. Since IL-10 has many anti-inflammatory functions, reduced IL-10 production may partly account for the increased pathogenicity associated with "alternative" Th17 cells. IL-10 can limit Th17-induced inflammation at several levels. A recent study demonstrated that IL-10 which may be produced directly by Th17 cells and also by regulatory Foxp $3^{+} \mathrm{T}$ cells and Tr1 cells - enables regulatory T cells to suppress Th17-induced inflammation [37]. In addition, Huber et al. demonstrated that IL- $17^{+}$as well as IL- $17^{+} \mathrm{IFN}-\gamma^{+} \mathrm{T}$ cells express higher levels of IL-10R $\alpha$ compared to IFN- $\gamma^{+} \mathrm{T}$ cells and that their proliferation is preferentially suppressed by IL-10 signaling [38]. Therefore, IL-10 not only limits Th17inflammation by promoting the regulatory functions of both Foxp $3^{+}$Tregs and Tr- 1 cells, but Th17 cells also seem to be more susceptible than other T effector cell subsets to direct inhibition by IL-10 signaling. Thus, in the absence of IL-23, Th17 cells may eventually start producing IL-10 in order to restrain themselves and prevent unnecessary tissue destruction. In addition, compared to other $\mathrm{T}$ effector cell subsets, Th17 cells are more susceptible to Tr-1 mediated suppression [38], since Tr-1 cells produce massive amounts of IL-10.

In the context of $\operatorname{Tr}-1$ and Th17 cells, it is also important to understand the role of the cytokine IL-21. Th17 cells are known to produce IL-21 and depend on it for selfamplification [39]. However, expression of IL-21 and IL-10 is driven by the transcription factor c-Maf [40,41], which is more highly expressed in "classical" Th17 cells [7] (see also Figure 1). In addition, T-bet, which is expressed in "alternative" Th17 cells, is known to down-regulate IL-21 [27]. Moreover, IL-21 is also important for the differentiation/ expansion of Tr-1 cells [40], which may limit expansion of Th17 cells. Therefore, IL-21 might be associated with "classical" more regulated Th17 cells rather than "alternative" 
more pathogenic Th17 cells. In support of this hypothesis, it has been shown that IL-21Rdeficient mice develop exacerbated EAE [42-44].

\section{GM-CSF is associated with Th17 pathogenicity}

Another factor that is differentially expressed in "alternative" vs. classical Th17 cells is GMCSF. Of note, GM-CSF is not exclusively produced by Th17 cells, but also by other T cell subsets including Th1 cells. However, two recent studies have described GM-CSF to be critical for the pathogenicity of Th17 cells during EAE [45,46]. El-Behi et al. [45] showed that TGF- $\beta$ suppresses GM-CSF production in Th17 cells, while IL-1 $\beta$ and especially IL-23 drive the production of GM-CSF, which - in a positive feedback loop - stimulates antigen presenting cells to produce more IL-23. Tying in with earlier work [47] Codarri et al. [46] demonstrated that IL-23 treated antigen-specific T cells are pathogenic even in the absence of both IL-17 and IFN- $\gamma$ due to their production of GM-CSF. There is conflicting data as to which transcription factors drive GM-CSF production. Although both studies agree that GM-CSF expression is not regulated by T-bet, Codarri et al. [46] advocate the concept that ROR- $\gamma \mathrm{t}$ drives GM-CSF expression, whereas El-Behi et al. [45] argue that ROR- $\gamma \mathrm{t}$ is unlikely to drive GM-CSF, since it is also found in T cell subsets that are not dependent of ROR- $\gamma t$ expression, such as Th1 cells. While the molecular mechanism of GM-CSFexpression remains to be identified, it is now clear that GM-CSF greatly contributes to the pathogenicity of "alternative" Th17 cells. GM-CSF not only induces antigen presenting cells to produce pro-inflammatory cytokines including IL- 6 and IL-23 and thereby promotes maturation/survival and de novo generation of Th17 cells, it also attracts a wave of secondary infiltrating cells - primarily macrophages, which then amplify the inflammatory process and promote tissue inflammation [45,46]. Therefore, the enhanced production of GM-CSF may partly explain why alternative Th17 cells are more difficult to regulate. However, it should be noted that GM-CSF alone may not be able to induce tissue inflammation in the absence of other cytokines produced by either Th1 or Th17 cells.

\section{Concluding remarks}

The plethora of data that has been generated in the field of Th17 differentiation and regulation since their discovery illustrates that Th17 cells cannot be defined using a narrow schematic, but that there is a wide spectrum of Th17 phenotypes with differences in their cytokine production and effector functions. The cytokine environment largely determines the expression of a network of different transcription factors that in turn determine the cytokines that are produced by Th17 cells. There is ample evidence that TGF- $\beta$ and IL-23 play major roles in shifting the Th17 phenotype towards "classical" and "alternative" phenotypes, respectively (Figure 1). However, many other cytokines contribute to the finetuning of the Th17 spectrum. Comparative molecular analysis of Th17 cells that produce IL-17, but differ in their ability to induce tissue inflammation and autoimmunity, will allow for identification of key molecules that mediate tissue inflammation and autoimmunity. Understanding not only the differentiating cytokines and transcription factors, but also the effector cytokines and functions associated with the different Th17 phenotypes, will enable us to develop therapeutic strategies in order to target Th17 cells that are pathogenic in autoimmune diseases.

One could speculate that it might be possible to shift the Th17 phenotype from the more pathogenic to the more regulated phenotype. Based on the studies by Huber [38] and Chaudry [37] described above, IL-10 is an intriguing candidate for such an approach, since it preferentially inhibits Th17 cells and is down-regulated in the "alternative" more pathogenic Th17 cells. 
Neutralization/inhibition of GM-CSF is another very promising candidate, since El-Behi [45] and Codarri [46] demonstrated that it is preferentially produced by alternative Th17 cells and is directly linked to pathogenicity.

In contrast to IFN- $\gamma$, which is not crucial for the pathogenicity of either Th1 or Th17 cells, T-bet is required for the development of tissue inflammation. This raises the question, which $\mathrm{T}$-bet dependent factors are responsible for the pathogenicity of effector $\mathrm{T}$ cells and would thus represent promising therapeutic targets.

Another great opportunity for the inhibition of Th17 cells has arisen through the discovery of synthetic ROR- $\gamma$ t-specific inhibitors/ligands such as Digoxin [48] and SR1001 [49]. ROR- $\gamma$ t not only transactivates IL-17, but may also control other molecules required for the pathogenicity of Th17 cells. Thus, developing small molecular weight compounds that inhibit ROR- $\gamma$ t function may provide therapeutic candidates for inhibiting tissue inflammation and autoimmunity.

\section{Acknowledgments}

This work was supported by grants from the NIH (R01NS045937, R01NS035685, R37NS030843, R01A1044880, P01A1039671, P01NS038037 and a Javits Neuroscience Investigator Award to V.K.K.) and the National Multiple Sclerosis Society (RG-2571 to V.K.K.).

\section{References and recommended reading}

1. Ivanov, McKenzie BS, Zhou L, Tadokoro CE, Lepelley A, Lafaille JJ, Cua DJ, Littman DR. The Orphan Nuclear Receptor RORgammat Directs the Differentiation Program of Proinflammatory IL-17(+) T Helper Cells. Cell. 2006; 126:1121-1133. [PubMed: 16990136]

2. Bettelli E, Carrier Y, Gao W, Korn T, Strom TB, Oukka M, Weiner HL, Kuchroo VK. Reciprocal developmental pathways for the generation of pathogenic effector TH17 and regulatory T cells. Nature. 2006; 441:235-238. [PubMed: 16648838]

3. Veldhoen M, Hocking RJ, Atkins CJ, Locksley RM, Stockinger B. TGFbeta in the context of an inflammatory cytokine milieu supports de novo differentiation of IL-17-producing T cells. Immunity. 2006; 24:179-189. [PubMed: 16473830]

4. Veldhoen M, Hocking RJ, Flavell RA, Stockinger B. Signals mediated by transforming growth factor-beta initiate autoimmune encephalomyelitis, but chronic inflammation is needed to sustain disease. Nat Immunol. 2006

5. Li MO, Wan YY, Flavell RA. T cell-produced transforming growth factor-beta1 controls T cell tolerance and regulates Th1- and Th17-cell differentiation. Immunity. 2007; 26:579-591. [PubMed: 17481928]

*6. Gutcher I, Donkor MK, Ma Q, Rudensky AY, Flavell RA, Li MO. Autocrine transforming growth factor-beta1 promotes in vivo Th17 cell differentiation. Immunity. 2011; 34:396-408. Shows for the first time that Th17 cells are a major source of TGF- $\beta$ and that they produce TGF- $\beta$ during inflammatory processes to promote Th17 differentiation. [PubMed: 21435587]

*7. Ghoreschi K, Laurence A, Yang XP, Tato CM, McGeachy MJ, Konkel JE, Ramos HL, Wei L, Davidson TS, Bouladoux N, et al. Generation of pathogenic T(H)17 cells in the absence of TGFbeta signalling. Nature. 2010; 467:967-971. Present evidence that alternative Th17 cells do not depend on TGF- $\beta$ and compare classical and alternative Th17 cells with microarray technology for the first time. [PubMed: 20962846]

8. Cua DJ, Sherlock J, Chen Y, Murphy CA, Joyce B, Seymour B, Lucian L, To W, Kwan S, Churakova $\mathrm{T}$, et al. Interleukin-23 rather than interleukin-12 is the critical cytokine for autoimmune inflammation of the brain. Nature. 2003; 421:744-748. [PubMed: 12610626]

9. Langrish CL, Chen Y, Blumenschein WM, Mattson J, Basham B, Sedgwick JD, McClanahan T, Kastelein RA, Cua DJ. IL-23 drives a pathogenic T cell population that induces autoimmune inflammation. J Exp Med. 2005; 201:233-240. [PubMed: 15657292] 
10. McGeachy MJ, Bak-Jensen KS, Chen Y, Tato CM, Blumenschein W, McClanahan T, Cua DJ. TGF-beta and IL- 6 drive the production of IL-17 and IL- 10 by T cells and restrain T(H)- 17 cellmediated pathology. Nat Immunol. 2007; 8:1390-1397. [PubMed: 17994024]

11. Awasthi A, Riol-Blanco L, Jäger A, Korn T, Pot C, Galileos G, Bettelli E, Kuchroo VK, Oukka M. Cutting edge: IL-23 receptor gfp reporter mice reveal distinct populations of IL-17-producing cells. J Immunol. 2009; 182:5904-5908. [PubMed: 19414740]

12. McGeachy MJ, Chen Y, Tato CM, Laurence A, Joyce-Shaikh B, Blumenschein WM, McClanahan TK, O'Shea JJ, Cua DJ. The interleukin 23 receptor is essential for the terminal differentiation of interleukin 17-producing effector T helper cells in vivo. Nat Immunol. 2009; 10:314-324. [PubMed: 19182808]

13. Jäger A, Dardalhon V, Sobel RA, Bettelli E, Kuchroo VK. Th1, Th17, and Th9 effector cells induce experimental autoimmune encephalomyelitis with different pathological phenotypes. $\mathrm{J}$ Immunol. 2009; 183:7169-7177. [PubMed: 19890056]

14. Acosta-Rodriguez EV, Napolitani G, Lanzavecchia A, Sallusto F. Interleukins 1beta and 6 but not transforming growth factor-beta are essential for the differentiation of interleukin 17-producing human T helper cells. Nat Immunol. 2007; 8:942-949. [PubMed: 17676045]

15. Wilson NJ, Boniface K, Chan JR, McKenzie BS, Blumenschein WM, Mattson JD, Basham B, Smith K, Chen T, Morel F, et al. Development, cytokine profile and function of human interleukin 17-producing helper T cells. Nat Immunol. 2007; 8:950-957. [PubMed: 17676044]

16. Yang L, Anderson DE, Baecher-Allan C, Hastings WD, Bettelli E, Oukka M, Kuchroo VK, Hafler DA. IL-21 and TGF-beta are required for differentiation of human T(H)17 cells. Nature. 2008; 454:350-352. [PubMed: 18469800]

17. Manel N, Unutmaz D, Littman DR. The differentiation of human $\mathrm{T}(\mathrm{H})-17$ cells requires transforming growth factor-beta and induction of the nuclear receptor RORgammat. Nat Immunol. 2008; 9:641-649. [PubMed: 18454151]

18. Park H, Li Z, Yang XO, Chang SH, Nurieva R, Wang YH, Wang Y, Hood L, Zhu Z, Tian Q, et al. A distinct lineage of CD4 $\mathrm{T}$ cells regulates tissue inflammation by producing interleukin 17 . Nat Immunol. 2005; 6:1133-1141. [PubMed: 16200068]

19. Harrington LE, Hatton RD, Mangan PR, Turner H, Murphy TL, Murphy KM, Weaver CT. Interleukin 17-producing CD4+ effector T cells develop via a lineage distinct from the $\mathrm{T}$ helper type 1 and 2 lineages. Nat Immunol. 2005; 6:1123-1132. [PubMed: 16200070]

20. Abromson-Leeman S, Bronson RT, Dorf ME. Encephalitogenic T cells that stably express both Tbet and ROR gamma t consistently produce IFNgamma but have a spectrum of IL-17 profiles. J Neuroimmunol. 2009; 215:10-24. [PubMed: 19692128]

21. Hue S, Ahern P, Buonocore S, Kullberg MC, Cua DJ, McKenzie BS, Powrie F, Maloy KJ. Interleukin-23 drives innate and T cell-mediated intestinal inflammation. J Exp Med. 2006; 203:2473-2483. [PubMed: 17030949]

22. Kullberg MC, Jankovic D, Feng CG, Hue S, Gorelick PL, McKenzie BS, Cua DJ, Powrie F, Cheever AW, Maloy KJ, et al. IL-23 plays a key role in Helicobacter hepaticus-induced T celldependent colitis. J Exp Med. 2006; 203:2485-2494. [PubMed: 17030948]

**23. Hirota K, Duarte JH, Veldhoen M, Hornsby E, Li Y, Cua DJ, Ahlfors H, Wilhelm C, Tolaini M, Menzel U, et al. Fate mapping of IL-17-producing T cells in inflammatory responses. Nat Immunol. 2011; 12:255-263. Generated a mouse that allows for the identification of all cells that have ever expressed IL-17 - thereby demonstrating clearly that the much debated IL- $17^{+} \mathrm{IFN}-\gamma^{+}$ double producers are exclusively derived from Th17 cells. [PubMed: 21278737]

24. Lee YK, Turner H, Maynard CL, Oliver JR, Chen D, Elson CO, Weaver CT. Late developmental plasticity in the T helper 17 lineage. Immunity. 2009; 30:92-107. [PubMed: 19119024]

25. Das J, Ren G, Zhang L, Roberts AI, Zhao X, Bothwell AL, Van Kaer L, Shi Y, Das G. Transforming growth factor beta is dispensable for the molecular orchestration of Th17 cell differentiation. J Exp Med. 2009; 206:2407-2416. [PubMed: 19808254]

26. Ahern PP, Schiering C, Buonocore S, McGeachy MJ, Cua DJ, Maloy KJ, Powrie F. Interleukin-23 drives intestinal inflammation through direct activity on T cells. Immunity. 2010; 33:279-288. [PubMed: 20732640] 
27. Lazarevic V, Chen X, Shim JH, Hwang ES, Jang E, Bolm AN, Oukka M, Kuchroo VK, Glimcher LH. T-bet represses $\mathrm{T}(\mathrm{H}) 17$ differentiation by preventing Runx 1-mediated activation of the gene encoding RORgammat. Nat Immunol. 2011; 12:96-104. [PubMed: 21151104]

28. Neurath MF, Weigmann B, Finotto S, Glickman J, Nieuwenhuis E, Iijima H, Mizoguchi A, Mizoguchi E, Mudter J, Galle PR, et al. The transcription factor T-bet regulates mucosal T cell activation in experimental colitis and Crohn's disease. J Exp Med. 2002; 195:1129-1143. [PubMed: 11994418]

29. Bettelli E, Sullivan B, Szabo SJ, Sobel RA, Glimcher LH, Kuchroo VK. Loss of T-bet, but not STAT1, prevents the development of experimental autoimmune encephalomyelitis. J Exp Med. 2004; 200:79-87. [PubMed: 15238607]

30. Shi G, Cox CA, Vistica BP, Tan C, Wawrousek EF, Gery I. Phenotype switching by inflammationinducing polarized Th17 cells, but not by Th1 cells. J Immunol. 2008; 181:7205-7213. [PubMed: 18981142]

31. Bending D, De La Pena H, Veldhoen M, Phillips JM, Uyttenhove C, Stockinger B, Cooke A. Highly purified Th17 cells from BDC2.5NOD mice convert into Th1-like cells in NOD/SCID recipient mice. J Clin Invest. 2009

32. Mangan PR, Harrington LE, O'Quinn DB, Helms WS, Bullard DC, Elson CO, Hatton RD, Wahl SM, Schoeb TR, Weaver CT. Transforming growth factor-b induces development of Th17 lineage. Nature. 2006; 441:231-234. [PubMed: 16648837]

33. Liu X, Leung S, Wang C, Tan Z, Wang J, Guo TB, Fang L, Zhao Y, Wan B, Qin X, et al. Crucial role of interleukin-7 in T helper type 17 survival and expansion in autoimmune disease. Nat Med. 2010; 16:191-197. [PubMed: 20062065]

34. Ferber IA, Brocke S, Taylor-Edwards C, Ridgway W, Dinisco C, Steinman L, Dalton D, Fathman CG. Mice with a disrupted IFN-gamma gene are susceptible to the induction of experimental autoimmune encephalomyelitis (EAE). J Immunol. 1996; 156:5-7. [PubMed: 8598493]

35. Jones LS, Rizzo LV, Agarwal RK, Tarrant TK, Chan CC, Wiggert B, Caspi RR. IFN-gammadeficient mice develop experimental autoimmune uveitis in the context of a deviant effector response. J Immunol. 1997; 158:5997-6005. [PubMed: 9190954]

36. Matthys P, Vermeire K, Mitera T, Heremans H, Huang S, Billiau A. Anti-IL-12 antibody prevents the development and progression of collagen-induced arthritis in IFN-gamma receptor-deficient mice. Eur J Immunol. 1998; 28:2143-2151. [PubMed: 9692883]

*37. Chaudhry A, Samstein RM, Treuting P, Liang Y, Pils MC, Heinrich JM, Jack RS, Wunderlich FT, Bruning JC, Muller W, et al. Interleukin-10 signaling in regulatory T cells is required for suppression of Th17 cell-mediated inflammation. Immunity. 2011; 34:566-578. [PubMed: 21511185]

*38. Huber S, Gagliani N, Esplugues E, O'Connor W Jr, Huber FJ, Chaudhry A, Kamanaka M, Kobayashi Y, Booth CJ, Rudensky AY, et al. Th17 cells express interleukin-10 receptor and are controlled by Foxp3 and Foxp3+ regulatory CD4+ T cells in an interleukin-10-dependent manner. Immunity. 2011; 34:554-565. Together with [*37] demonstrates that IL-10 is especially suited to inhibit Th17 cells both directly and indirectly via regulatory T cells. [PubMed: 21511184]

39. Korn T, Bettelli E, Gao W, Awasthi A, Jäger A, Strom TB, Oukka M, Kuchroo VK. IL-21 initiates an alternative pathway to induce proinflammatory T(H)17 cells. Nature. 2007; 448:484-487. [PubMed: 17581588]

40. Pot C, Jin H, Awasthi A, Liu SM, Lai CY, Madan R, Sharpe AH, Karp CL, Miaw SC, Ho IC, et al. Cutting edge: IL-27 induces the transcription factor c-Maf, cytokine IL-21, and the costimulatory receptor ICOS that coordinately act together to promote differentiation of IL-10-producing $\operatorname{Tr} 1$ cells. J Immunol. 2009; 183:797-801. [PubMed: 19570826]

41. Spolski R, Kim HP, Zhu W, Levy DE, Leonard WJ. IL-21 mediates suppressive effects via its induction of IL-10. J Immunol. 2009; 182:2859-2867. [PubMed: 19234181]

42. Coquet JM, Chakravarti S, Smyth MJ, Godfrey DI. Cutting edge: IL-21 is not essential for Th17 differentiation or experimental autoimmune encephalomyelitis. J Immunol. 2008; 180:7097-7101. [PubMed: 18490706] 
43. Sonderegger I, Kisielow J, Meier R, King C, Kopf M. IL-21 and IL-21R are not required for development of Th17 cells and autoimmunity in vivo. Eur J Immunol. 2008; 38:1833-1838. [PubMed: 18546146]

44. Liu R, Bai Y, Vollmer TL, Bai XF, Jee Y, Tang YY, Campagnolo DI, Collins M, Young DA, La Cava A, et al. IL-21 receptor expression determines the temporal phases of experimental autoimmune encephalomyelitis. Exp Neurol. 2008; 211:14-24. [PubMed: 18353312]

*45. El-Behi M, Ciric B, Dai H, Yan Y, Cullimore M, Safavi F, Zhang GX, Dittel BN, Rostami A. The encephalitogenicity of $\mathrm{T}(\mathrm{H}) 17$ cells is dependent on IL-1- and IL-23-induced production of the cytokine GM-CSF. Nat Immunol. 2011; 12:568-575. [PubMed: 21516111]

*46. Codarri L, Gyulveszi G, Tosevski V, Hesske L, Fontana A, Magnenat L, Suter T, Becher B. RORgammat drives production of the cytokine GM-CSF in helper T cells, which is essential for the effector phase of autoimmune neuroinflammation. Nat Immunol. 2011; 12:560-567. Together with [*45] demonstrates that the pathogenicity of Th17 cells largely depends on the production of GM-CSF, which is dependent on IL-23R signalling. [PubMed: 21516112]

47. Kroenke MA, Chensue SW, Segal BM. EAE mediated by a non-IFN-gamma/non-IL-17 pathway. Eur J Immunol. 2010; 40:2340-2348. [PubMed: 20540117]

48. Huh JR, Leung MW, Huang P, Ryan DA, Krout MR, Malapaka RR, Chow J, Manel N, Ciofani M, Kim SV, et al. Digoxin and its derivatives suppress TH17 cell differentiation by antagonizing RORgammat activity. Nature. 2011; 472:486-490. [PubMed: 21441909]

49. Solt LA, Kumar N, Nuhant P, Wang Y, Lauer JL, Liu J, Istrate MA, Kamenecka TM, Roush WR, Vidovic D, et al. Suppression of TH17 differentiation and autoimmunity by a synthetic ROR ligand. Nature. 2011; 472:491-494. [PubMed: 21499262] 


\section{Highlights}

- The Th17 cell spectrum ranges from "classical" to "alternative" Th17 cells

- "Classical" Th17 cells depend on TGF- $\beta$, are more regulated and less pathogenic

- "Alternative" Th17 cells depend on IL-23, are less regulated and more pathogenic 


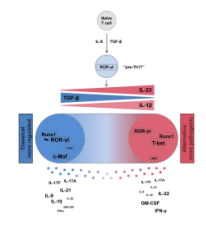

Figure 1.

Th17 cells comprise a spectrum ranging from the "classical" more regulated Th17 cell to the "alternative" more pathogenic Th17 cell. 